\title{
Correlation Between Types of Bacteria with Pathology Examination of Chorioamnion from Preterm Birth
}

\author{
Hubungan antara Jenis Bakteri dengan \\ Pemeriksaan Patologi Anatomi Selaput Korioamnion pada Persalinan Kurang Bulan
}

\author{
Fita Drisma, Budi Handono, Ruswana Anwar \\ Department of Obstetrics and Gynecology \\ Faculty of Medicine University of Padjadjaran/ \\ Dr. Hasan Sadikin Hospital \\ Bandung
}

\begin{abstract}
Objective: To determine whether there is a correlation between the types of bacteria found in amniotic membrane and intrauterine infection causing preterm delivery.

Method: This was an experimental study. We studied the amniotic membrane from patients undergoing spontaneous preterm delivery, both with premature rupture of membrane and intact membrane in Dr. Hasan Sadikin Hospital and some district Hospitals around Dr. Hasan Sadikin Hospital that fulfill the inclusions and exclusion criterias. Experiments were performed in Prodia Laboratory and Pathology Department of Dr. Hasan Sadikin Hospital. The amniotic membrane was prepared in Brain Heart Infusion Broth (BHI) and Formalin. The sample prepared in BHI was then transported to the laboratory and cultured for bacteria within 24 hours after the sample was taken, and the other sample prepared in formalin was made into tissue blocks and stained with hematoxylin and eosin. Afterwards, we counted the polymorph nuclear cells and if there were more than 4 cells in view, we concluded that there was an intrauterine infection.

Result: Types of bacteria and intrauterine infection found in both groups showed a significant difference $(\mathrm{p}=0.002)$ between the groups with PROM and the group with intact amniotic membrane. The most bacteria found in preterm delivery with amnion membrane intact was Eschericia coli (33.3\%) and Streptococcus alfa hemolytic (33.3\%) in premature rupture of the membrane. Based on Rank Spearman Correlation test shows a significant $(p<0.05)$ positive correlation between intrauterine infection with preterm delivery with amniotic membrane intact and premature rupture of the membrane.
\end{abstract}

Conclusion: There is a correlation between types of bacteria invading the amniotic membrane causing intrauterine infection that initiates preterm delivery.

[Indones J Obstet Gynecol 2012; 36-2: 71-4]

Keywords: amniotic membrane, bacteria, intrauterine infection, preterm delivery

\section{Abstrak}

Tujuan: Menentukan apakah terdapat hubungan antara jenis bakteri dari selaput ketuban pada persalinan kurang bulan dengan infeksi intra uterus yang menyebabkan persalinan preterm.

Metode: Penelitian ini merupakan penelitian eksperimental yang dilakukan terhadap selaput ketuban dari pasien yang mengalami persalinan kurang bulan secara spontan dengan ketuban pecah dini maupun tanpa ketuban pecah dini di RS Dr. Hasan Sadikin dan rumah sakit jejaring yang memenuhi kriteria inklusi dan eksklusi. Eksperimen ini dilakukan di Laboratorium Prodia dan Laboratorium Patologi Anatomi RS Dr. Hasan Sadikin. Selaput ketuban disiapkan dengan memasukkan dalam tabung yang berisi Brain Heart Infusion Broth (BHI) dan Formalin sebagai media transportasi ke laboratorium. Sampel dalam BHI akan dikultur dalam waktu 24 jam setelah sampel diambil dan selaput ketuban yang berada dalam larutan formalin akan dilakukan pewarnaan paraffin blok dan diberi pewarnaan Hematoxylin dan eosin. Kemudian, akan dilakukan penghitungan jumlah sel polimorfonukleus (PMN) perlapang pandang. Bila terdapat $>4$ sel PMN perlapang pandang maka dinyatakan bahwa terdapat infeksi intrauterin.

Hasil: Jenis bakteri dan infeksi intra uterus dari kedua kelompok menunjukkan perbedaan yang bermakna $(p=0,002)$. Bakteri terbanyak yang ditemukan pada persalinan kurang bulan tanpa ketuban pecah adalah Eschericia coli (33,3\%) dan Streptococcus alfa hemolitik $(33,3 \%)$ pada ketuban pecah dini. Berdasarkan uji korelasi Rank Spearman maka sangat signifikan $(p<0,05)$ korelasi positif antara infeksi intrauterin pada persalinan kurang bulan dengan ketuban pecah dini dengan tanpa ketuban pecah dini.

Kesimpulan: Terdapat korelasi antara invasi bakteria dengan infeksi intrauterin antara bakteri yang menginvasi selaput ketuban dan menginisiasi persalinan kurang bulan.

[Maj Obstet Ginekol Indones 2012; 36-2: 71-4]

Kata kunci: bakteri, infeksi intrauterin, persalinan kurang bulan, selaput ketuban

Correspondence: Fita Drisma, Department of Obstetrics and Gynecology, Faculty of Medicine University of Padjadjaran, Bandung. Telephone: 081360262180, Email: fita94@yahoo.com

\section{INTRODUCTION}

Prematurity is the leading cause of perinatal morbidity and mortality worldwide. Intrauterine infection has emerged as a major cause of premature labor and delivery. It has been estimated that $25 \%$ of all preterm deliveries occur to mothers who have bacteria invasion of the amniotic cavity, although these infections are mostly subclinical in 
nature. This research describes the pathways leading to intrauterine infection, microbiology, frequency and clinical consequences of infection. The pathophysiology of the fetal inflammatory response syndrome is reviewed, as is its relationship to long-term handicap, such as cerebral palsy and bronchopulmonary dysplasia. ${ }^{1-5}$ The fact that preterm delivery may occur in association with leukocytosis of the amniotic fluid or chorioamnion has long been recognized.6,7

\section{METHODS}

Amniotic membrane was collected from patients that had preterm spontaneous delivery. Two groups of patients were identified: 1 ) patients with PPROM and spontaneous preterm delivery $(\mathrm{n}=25)$, and 2) patients with spontaneous preterm delivery, but the membrane is still intact $(n=25)$. A $2 \times 2$ $\mathrm{cm}$ sample of the amniotic membrane was taken from the two groups and placed into glass tubes filled with Brain Heart Infusion Broth (BHI) and another amniotic membrane was taken and put into a pot that was filled with formalin and sent to the laboratory. The amniotic membrane was cultured for bacteria and pathology examination was done to identify the number of polymorphonuclear (PMN) that were 5 to 10 or more per high-power field were scored as a PMN infiltration meaning that there was an intrauterine infection.

We used Chi Square Test using SPSS computer package (Release 17.0, SPSS, Chicago, IL, USA) to compare the types of bacteria found on both groups and if they cause intrauterine infections causing preterm delivery. The normality test was analyzed using Saphiro Wilk test. Parameters were expressed as a percentage. The statistical significance of differences was considered significant if $p$ value was less than 0.05 .

\section{RESULTS}

Table 1. Types of bacteria according to the pathology examination of amniotic membrane

\begin{tabular}{|c|c|c|c|c|c|}
\hline & & \multicolumn{3}{|c|}{ Polimorfonuclear } & \multirow[t]{2}{*}{ Total } \\
\hline & & - & $\begin{array}{l}>4 \\
\text { Fokal }\end{array}$ & $\begin{array}{c}>10 \\
\text { Diffuse }\end{array}$ & \\
\hline \multirow[t]{5}{*}{$\begin{array}{l}\text { Types } \\
\text { Bacteria }\end{array}$} & E. coli & $\begin{array}{c}0 \\
0 \%\end{array}$ & $\begin{array}{c}8 \\
44.4 \%\end{array}$ & $\begin{array}{c}5 \\
20.8 \%\end{array}$ & $\begin{array}{c}13 \\
26.0 \%\end{array}$ \\
\hline & $\begin{array}{l}\text { Staphylococ- } \\
\text { cus aureus }\end{array}$ & $\begin{array}{c}0 \\
0 \%\end{array}$ & $\begin{array}{c}6 \\
33.3 \%\end{array}$ & $\begin{array}{c}4 \\
16.7 \%\end{array}$ & $\begin{array}{c}10 \\
20.0 \%\end{array}$ \\
\hline & $\begin{array}{l}\text { Streptococcus } \\
\text { alfa hemolytic }\end{array}$ & $\begin{array}{c}4 \\
50.0 \%\end{array}$ & $\begin{array}{c}3 \\
16.7 \%\end{array}$ & $\begin{array}{c}6 \\
25.0 \%\end{array}$ & $\begin{array}{c}13 \\
26.0 \%\end{array}$ \\
\hline & $\begin{array}{l}\text { Micrococ- } \\
\quad \text { cus Sp }\end{array}$ & $\begin{array}{c}2 \\
25.0 \%\end{array}$ & $\begin{array}{c}1 \\
5.6 \%\end{array}$ & $\begin{array}{c}5 \\
20.8 \%\end{array}$ & $\begin{array}{c}8 \\
16.0 \%\end{array}$ \\
\hline & $\begin{array}{l}\text { Corynebac- } \\
\text { terium Sp }\end{array}$ & $\begin{array}{c}2 \\
25.0 \%\end{array}$ & $\begin{array}{c}0 \\
.0 \%\end{array}$ & $\begin{array}{c}4 \\
16.7 \%\end{array}$ & $\begin{array}{c}6 \\
12.0 \%\end{array}$ \\
\hline Total & & $\begin{array}{c}8 \\
100.0 \%\end{array}$ & $\begin{array}{c}18 \\
100.0 \%\end{array}$ & $\begin{array}{c}24 \\
100.0 \%\end{array}$ & $\begin{array}{c}50 \\
100.0 \%\end{array}$ \\
\hline
\end{tabular}

There were significant differences the types of bacteria between preterm delivery with membrane intact and PPROM. Both groups of preterm delivery were caused by chorioamnionitis.

\section{DISCUSSION}

This study showed that there were significant effects of infection towards the occurrence of preterm delivery. The most frequent types of bacteria causing infections were Escherichia coli and Staphylococcus aureus.

The best-studied site of infection is the amniotic fluid. As well as containing bacteria, amniotic fluid from women with intrauterine infections has lower glucose concentrations, higher white-cell counts,

Table 2. Comparison of the types of bacteria with the incidence of infection

\begin{tabular}{|c|c|c|c|c|c|c|}
\hline & \multicolumn{5}{|c|}{ Bacteria Types } & \multirow[b]{2}{*}{ Total } \\
\hline & E coli & $\begin{array}{c}\text { Staphylococcus } \\
\text { aureus }\end{array}$ & $\begin{array}{c}\text { Streptococcus a } \\
\text { hemolytic }\end{array}$ & Micrococcus SP & $\begin{array}{c}\text { Corynebacterium } \\
\text { SP }\end{array}$ & \\
\hline \multirow[t]{2}{*}{ Infection (+) } & 13 & 10 & 13 & 2 & 1 & 39 \\
\hline & $33 \%$ & $25.6 \%$ & $33 \%$ & $5.1 \%$ & $2.6 \%$ & $100 \%$ \\
\hline \multirow[t]{2}{*}{ Infection (-) } & 0 & 0 & 0 & 6 & 5 & 11 \\
\hline & $0 \%$ & $0 \%$ & $0 \%$ & $54,5 \%$ & $45,5 \%$ & $100 \%$ \\
\hline \multirow[t]{2}{*}{ Total } & 13 & 10 & 13 & 8 & 6 & 50 \\
\hline & $26 \%$ & $20 \%$ & $26 \%$ & $16 \%$ & $12 \%$ & $100 \%$ \\
\hline
\end{tabular}


and higher concentrations of complement $\mathrm{C} 3$ and various cytokines than fluid from uninfected women. ${ }^{8}$ However, detecting bacteria or measuring cytokines and other analyses in amniotic fluid requires amniocentesis, and it is not clear that amniocentesis improves the outcome of pregnancy, even in women with symptoms of preterm labor. At present, it is not appropriate to obtain amniotic fluid routinely to test for intrauterine infection in women who are not in labor. It is believed that intrauterine infection disrupts the extracellular choriodecidual basement membrane, causing leakage of this protein into the cervix and vagina. ${ }^{9-11}$

Some studies have shown several types of microorganisms from the amniotic cavity from women with preterm labor and intact membranes, some of them are Ureaplasma urealyticum, Fusobacterium spp. and Mycoplasma hominis. ${ }^{12}$ Other microorganisms that have been found in the amniotic fluid include Streptococcus agalactiae, Staphylococcus aureus, Gardnerella vaginalis, Escherichia coli Clostridium spp.13-17 In other studies, Cassel et al reported the retrieval of genital Mycoplasma organisms from amniotic fluid samples collected by amniocentesis at 16-21 week gestation. ${ }^{18}$ Subsequently, Gray et al reported positive cultures for $U$. urealyticum in amniotic fluid samples obtained during second trimester genetic amniocentesis. ${ }^{19}$ These observations suggest that microbial invasion can be clinically silent in the midtrimester of pregnancy and that pregnancy loss and preterm delivery can take weeks to occur. A similar finding was reported by Horowitz et al who detected $U$. urealyticum in $2.8 \%$ of amniotic fluid samples obtained at $16-20$ wk gestation. The rate of adverse pregnancy outcome (fetal loss, preterm delivery and low birth weight) was significantly higher in patients with a positive amniotic fluid culture than in those with a negative culture. ${ }^{20}$

\section{CONCLUSIONS}

We have demonstrated that both groups with preterm delivery were caused by intrauterine infection that would lead to the increase incidence of morbidity and mortality to the neonate. This indicates that infection involves the incidence of preterm delivery. Vaginal swab should be done to women with premature contraction to identify whether there were any bacteria so then we can give medication to prevent infection to give further effect in causing preterm delivery.

\section{REFERENCES}

1. Cunningham FG, Gant NF, Leveno KJ, Gillstrap LC, Hauth JC, Wenstrom KT. Williams Obstetrics. 22 ${ }^{\text {nd }}$ edition. London: McGraw-Hill; 2006

2. Goldenberg RL, Rouse DJ. Prevention of premature birth. Med Prog. 1998; 339(5): 313-20

3. Romero R, Chaiworapongsa T. Preterm labor, intrauterine infection and the fetal inflammatory response syndrome. Neo reviews. 2002; 3: 73-81

4. Stubblefield PG. Causes and prevention of premature birth: an overview. In: Fuch AR, Fuch F, Stubblefield PG, ed. Preterm birth causes, prevention and management. $2^{\text {nd }}$ edition. New York McGraw-Hill; 1993: 3-35

5. Walkinshaw SA. Preterm labour and delivery of the preterm infant. In: Chamberlain G, Steer P, ed. Turnbull's Obstetrics. $3^{\text {rd }}$ edition. London: Churchill Livingstone, Elsevier science limited; 2002: 493-514

6. Romero R, Gomez R, Chaiworapongsa T, Conoscenti G, Kim JC, Kim YM. The role of infection in preterm labour and delivery. Pediatric Perinatal Epidemiol. 2001; 15(2): 41-56

7. Hillier M, Kiviat N. A case cotrol study of chorioamnionic infection and histologic chorioamnionitis in prematurity. $\mathrm{N}$ Engl J Med. 1988; 319: 972-8

8. Gonzales LF, Chariworapongsa T, Romero R. Intrauterine infection, preterm parturition and the fetal inflammatory response syndrome. In: James D, Steer P, Weiner C, Gonik B, ed. High risk pregnancy: management option. $3^{\text {rd }}$ edition. Philadelphia: Elsevier-Saunders; 2006: 583-665

9. Hay P, Sharland M, Ugwumadu A. Infection in pregnancy. In: Chamberlain G, Steer P, ed. Turnbull's Obstetrics. $3^{\text {rd }}$ edition. London: Churchill Livingstone; 2002

10. Cram LF, Zapata MI, Toy EC, Baker B. Genitourinary infections and their association with preterrm labor. Am Fam Physician. 2002; 65(2): 241-8

11. Sabina Cauci JFC. High Sialidase levels increase preterm birth risk among women who are bacterial vaginosispositive in early gestation. Am J Obstet Gynecol. 2010: 203

12. Laura L. Klein RSG. Use of microbial cultures and antibiotics in the prevention of infection-associated preterm birth. Am J Obstet Gynecol. 2004: 190

13. Kyung Joon Oh KAL, Yoo-Kyung Sohn. Intraamniotic infection with genital mycoplasmas exhibits a more intense inflamatory response than intraamniotic infection with other microorganisms in patients with preterm premature rupture of membranes. Am J Obstet Gynecol. 2010; 203: 1-8

14. Romero R, Chaiworapongsa T, Espinoza J. Micronutrients and intrauterine infection, preterm birth and the fetal inflammatory response syndrome. J Nutr. 2003; 133: 1668-73

15. Goldenberg RI CJ, Iams JD, Romero R. Epidemiology and causes of preterm birth. Lancet. 2008; 371: 75-82

16. Goldenberg R, Hauth J, Andrews W. Intrauterine infection and preterm delivery. N Engl J Med. 2000; 342: 1500-7 
17. Singh Uma, Singh Nisha, Seth Shikha. A prospective analysis of etiology and outcome of preterm labor J Obstet Gynecol India. 2007; 57(1): 48-52

18. Cassell GH, Davis RO, Waites KB, Brown MB, Marriott PA, Stagno S, Davis JK. Isolation of Mycoplasma hominis and Ureaplasma urealyticum from amniotic fluid at 16-20 weeks of gestation: potential effect on outcome of pregnancy. Sex Transm Dis. 1983; 10: 294-302
19. Gray DJ, Robinson HB, Malone J, Thomson RB Jr. Adverse outcome in pregnancy following amniotic fluid isolation of Ureaplasma urealyticum. Prenat Diagn. 1992; 12: 111-7

20. Horowitz S, Mazor M, Romero R, Horowitz J, Glezerman M. Infection of the amniotic cavity with Ureaplasma urealyticum in the midtrimester of pregnancy. J Reprod Med. 1995; 40: 375-9 